\title{
Izabela Bawej
}

Uniwersytet Kazimierza Wielkiego w Bydgoszczy

\section{SPRAWNOŚĆ PISANIA NA POZIOMIE ZAAWANSOWANYM. PREZENTACJA WYBRANYCH WYNIKÓW BADAŃ NA PRZYKŁADZIE PNJN - PISANIE Z ORTOGRAFIĄ}

\author{
SUMMARY \\ Writing skill in the higher education (exemplified by selected results \\ of questionnaire study to teach German)
}

The aim of this article is to discuss the phenomenon of writing skill in the process of foreign language learning. In the first part of the article the Author tries to describe the notion of writing in the communication. This paper is based not only on the theoretical considerations about the problem of writing at the advanced level but also contains conclusions drawn from the action research. She tries to show and to explain the status of the writing skill in German. In the second part the paper presents the results of a quantitative-qualitative study made among students of Applied Linguistics who learn German as a foreign language.

Key words: writing, German, language, speech, communication

\section{ZUSAMMENFASSUNG}

Schreiben auf dem fortgeschrittenen Niveau. Zu ausgewählten Ergebnissen der Untersuchungen am Beispiel des Faches Praktischer Unterricht - Schreiben mit der deutschen Rechtschreibung

Der vorliegende Artikel beschäftigt sich mit dem Phänomen der Fertigkeit Schreiben im fremdsprachlichen Deutschunterricht. Es gibt heute kaum Zweifel, dass Schreiben einen wichtigen Platz im Lernprozess fortgeschrittener Lerner hat. Im theoretischen Teil des Artikels 
werden die Rolle und das Wesen der Schreibkompetenz in der Fremdsprachendidaktik diskutiert. Im zweiten Teil wird eine Befragung von den Deutsch lernenden Studenten der Fachrichtung Angewandte Linguistik zur Rolle der Fertigkeit Schreiben in der deutschen Sprache dargestellt.

\section{Wstęp}

Znajomość języków obcych jest dzisiaj nieodzowną umiejętnością. Zmiany polityczne i gospodarcze, wydarzenia kulturalne oraz masowy przepływ informacji sprawiają, że sprawna komunikacja w językach obcych zarówno w formie ustnej, jak i pisemnej, jest koniecznością i jednym z podstawowych elementów dobrego wykształcenia każdego z nas.

Pomimo że żyjemy w XXI wieku, a nasze codzienne życie jest zdominowane przez telewizję i telefony komórkowe, nie możemy mówić o zmierzchu epoki pisania. Nieustannie bowiem wykorzystujemy tę umiejętność, załatwiając codzienne sprawy, np.: robimy listy zakupów, zapisujemy sobie, co mamy danego dnia do załatwienia, zostawiamy na kartkach informacje dla najbliższych, wypełniamy formularze czy odpowiadamy na korespondencję urzędową. Rozwój nowych technologii informatycznych (Internet - blogi, fora internetowe, poczta elektroniczna) i telefonicznych (smsy, różnorodne aplikacje mobilne, np. notesy, organizatory) także wymagają od nas umiejętności pisania. Umiejętność posługiwania się pismem, tworzenia tekstów pisemnych i korzystania z przekazów $\mathrm{w}$ formie pisemnej, jest wciąż w cenie i świadczy o rozwoju kulturalnym, o poziomie intelektualnym i językowym każdego z nas.

Pisanie - czy to w języku ojczystym, czy w języku obcym - jest sprawnością przydatną nie tylko $\mathrm{w}$ życiu codziennym, ale także $\mathrm{w}$ warunkach szkolnych, na przykład na poziomie akademickim na różnego rodzaju egzaminach czy testach, które najczęściej mają charakter pisemny. Pisanie to bardzo dobra metoda kształcenia umiejętności analizy, formułowania wniosków i argumentacji. Dla absolwenta kierunku filologicznego czy studiów neofilologicznych powinna to być podstawowa umiejętność. Dlatego w niniejszych rozważaniach spróbowano odpowiedzieć na pytanie, jaką rolę odgrywa sprawność pisania w języku niemieckim na etapie zaawansowanym i czy warto w ogóle uczyć się jeszcze pisania w tym języku, zwłaszcza w dobie stałego wzrostu popularności języka angielskiego. Odpowiedzi tej udzielono na podstawie wybranej literatury przedmiotu i danych uzyskanych za pomocą ankiet przeprowadzonych w latach 2010-2013 wśród studentów III roku lingwistyki stosowanej Uniwersytetu Kazimierza Wielkiego w Bydgosz- 
czy w ramach przedmiotu Praktyczna Nauka Języka Niemieckiego - pisanie z ortografia.

\section{Język, mowa, pismo}

Język jest dla przeciętnego człowieka zjawiskiem tak bardzo oczywistym, że aż niezauważalnym. Przeważnie utożsamia on język z mową. W językoznawstwie odróżnia się jednak język od sposobów jego funkcjonowania. Językiem nazywa się pewien byt abstrakcyjny (system znaków), a za manifestację tego abstraktu uważa się teksty ${ }^{1}$.

Istnieją dwa przeciwstawne stanowiska dotyczące stosunku między językiem a mową i pismem. Istotę tych stanowisk można zrozumieć na przykładzie definicji pisma. Według pierwszego pismo jest systemem graficznym, który odzwierciedla język mówiony. Zgodnie z tym stanowiskiem język mówiony jest nadrzędny w stosunku do języka pisanego. Drugie stanowisko interpretuje język jako pojęcie nadrzędne, któremu podporządkowane są dwa subkody: mowa i pismo. System językowy przejawia się w tekstach, które przybierają formę substancji fonicznej (teksty mówione) lub graficznej (teksty pisane) ${ }^{2}$.

Przyczyn rozbieżności w odniesieniu do systemu języka oraz jego formy pisanej i mówionej upatruje się w historii lingwistyki. Ferdinand de Saussure uznał język pisany za wtórny. Mowie przyznaje się status języka ważniejszego, a pismo nazywa językiem drugim. Jeżeli weźmiemy pod uwagę powstanie języka pisanego i jego rozwój historyczny, język pisany jest rzeczywiście wtórny w stosunku do języka mówionego. Z punktu widzenia historii ludzkości pismo jest „młodszym” wynalazkiem. Również w rozwoju każdego człowieka mowa pojawia się wcześniej niż pismo. Mowa jest także bardziej uniwersalna, gdyż jedną z podstawowych więzi kulturowych ludzi na świecie jest ustna forma komunikacji językowej. Mowa jest najczęściej wykorzystywana w komunikacji bezpośredniej i jest silniej wspierana przez kontekst sytuacyjny oraz elementy niewerbalne, np.: gesty, mimikę, kontakt wzrokowy, postawę ciała czy wygląd fizyczny. Pismo służy komunikacji pośredniej, a osoba pisząca najczęściej abstrahuje od sytuacji, w której pisze ${ }^{3}$.

1 Por. E. Awramiuk, Lingwistyczne podstawy poczatkowej nauki czytania i pisania po polsku, Białystok 2006, s. 26.

2 Por. ibidem; por. także H. Glück, Schreiben in der Fremdsprache Deutsch. Eine Einführung, [w:] Texte schreiben im Germanistik Studium, M. Lieber, J. Posset (red.), München 1988, s. 26.

3 Por. E. Awramiuk, Lingwistyczne podstawy..., s. 26, 30; I. Bawej, Pisemna forma komunikacji językowej w procesie nauki języka obcego, „Linguistica Bidgostiana” 2008, t. V, s. 23-24. 
Przyjmuje się, że umiejętność posługiwania się mową jest właściwa każdemu człowiekowi o normalnym rozwoju psychofizycznym. Wszystkie znane społeczności ludzkie posługują się mową jako podstawowym środkiem komunikacji. Stąd też mówi się o naturalnym związku człowieka z mową. Z pisaniem jest nieco inaczej. Pismo nie jest naturalną umiejętnością człowieka, lecz osiągnięciem cywilizacyjnym, wyuczonym sposobem przekazywania i utrwalania informacji. W piśmie, na przykład, przechowywany jest dorobek intelektualny i artystyczny danej społeczności. Wiele społeczeństw, które charakteryzują się odrębnością językową, nie wytworzyło pisma. Umiejętność posługiwania się językiem pisanym nie jest też powszechna w społeczeństwach posiadających pismo, czego dowodem są coraz częściej spotykane zjawiska dysgrafii i dysleksji u dzieci i młodzieży ${ }^{4}$.

Dodajmy w tym kontekście, iż pismo nie powstało jako graficzny odpowiednik ciągów dźwięków mowy. Nasi praprzodkowie wykorzystali posiadaną sprawność w posługiwaniu się narzędziami, które służyły im do zdobywania pożywienia i przystosowania środowiska do swoich celów, do pozostawiania śladów o wartości informacyjnej na powierzchni przedmiotów, kości, kamieni czy skał. Według archeologów systemy graficzne przekazywania i przechowywania informacji zrodziły się z prozaicznych potrzeb. Na przykład właściciele dóbr materialnych, aby mieć kontrolę nad swoim majątkiem, tworzyli coś w rodzaju ksiąg inwentarzowych w postaci kamieni czy glinianych tabliczek, na których wyryto rysunki zwierząt domowych i roślin zbożowych oraz symbole ilości. Pismo nie powstało zatem z naśladowania mowy, lecz ma swoje źródło w rysunku. Naukowcy przyjmują, że najstarszym typem graficznego sposobu komunikacji jest pismo piktograficzne. Jego początków można doszukiwać się w zachowanych rytach i malowidłach skalnych sprzed kilkunastu tysięcy lat ${ }^{5}$.

Można więc przyjąć, że język jest narzędziem porozumiewania się ludzi, a jego sposobami realizacji są język mówiony i język pisany.

\section{Istota pisania}

Ponieważ mowa ma charakter prymarny, jest starsza i stosowana na szerszą skalę niż pismo, zaś dzieci zawsze uczą się mówić, zanim nauczą się pisać, w dydaktyce nauczania języków obcych istnieje tendencja do traktowania prymatu mowy nad pismem jako generalnego celu kształcenia. Podporządkowanie pisma mowie przez długie lata spowodowało, że sprawność pisania pozostawała i często

4 Por. E. Łuczyński, J. Maćkiewicz, Językoznawstwo ogólne. Wybrane zagadnienia, Gdańsk 2002, s. 59, 67.

5 Por. ibidem, s. 60. 
nadal pozostaje na marginesie zainteresowań wielu nauczycieli, ponieważ teksty uczniów trzeba czytać, analizować i poprawiać, co dla wielu osób jest dodatkową pracą. Biorąc pod uwagę rolę umiejętności pisania we współczesnym świecie, można określić taką sytuację jako paradoksalną.

Pisanie jest formą komunikacji językowej o złożonym charakterze, która ma swoją specyfikę, przebieg i tylko sobie właściwe rodzaje. Dlatego pisanie, nawet w języku ojczystym, nie jest łatwą umiejętnością. Wiele osób potrafi coś przeczytać (mniej lub bardziej płynnie), ale bardzo często nie potrafi tego opowiedzieć, a tym bardziej poprawnie napisać.

Pisanie zawiera w sobie wiele elementów składowych, które muszą być uwzględnione przez piszącego, np.: realizacja zadania zgodnie z treścią polecenia, język (w tym kontekście jest to język obcy), forma tekstu, treść tekstu, osoba piszącego (jego wiedza strategiczna, na przykład transfer wcześniejszych doświadczeń w pisaniu w języku ojczystym; procesy kognitywne uaktywniane podczas pisania, na przykład znajdowanie myśli, które będą potem wykorzystane do realizacji tematu, planowanie organizacji tekstu, układanie myśli w całość w formie tekstu i analiza powstałego tekstu; sfera afektywna, na przykład wewnętrzne zahamowania związane z podjęciem pisania - syndrom pustej kartki - czy z koniecznością oddania pracy do oceny, często związane z niską samooceną własnych umiejętności językowych), osoba czytającego (wymagania odbiorcy co do formalności języka, formatu tekstu czy poprawności gramatycznej) ${ }^{6}$.

Spróbujmy wyjaśnić, w którym momencie pisanie staje się trudne. W tworzeniu wypowiedzi pisemnych wyróżnia się trzy zasadnicze etapy: 1) manipulowanie systemem graficznym, 2) kodowanie strukturalne i 3) komunikowanie znaczenia. W przypadku osób uczących się języka obcego, których język ojczysty posługuje się tym samym systemem graficznym co nabywany język obcy, uczący się nie mają raczej trudności na etapie manipulowania systemem graficznym. Kłopoty zaczynają się przeważnie na etapie kodowania strukturalnego oraz na poziomie zdań. Jak wynika z literatury przedmiotu i sprawozdań z egzaminów, uczący się mają bardzo często trudności, nawet w ich własnym języku, z napisaniem dłuższego spójnego tekstu, chociaż nie mają większych kłopotów w strukturalnym kodowaniu wypowiedzi ustnych. Trudności w pisaniu mogą także wystąpić na etapie komunikowania, ponieważ okoliczności, w których odbywa się komunikacja pisemna oraz cele społeczne, którym ona służy, nie są takie same jak w komunikacji ustnej, a dla osób uczących się języków obcych różnica pomiędzy tymi dwoma sposobami komunikacji ma decydujące znaczenie ${ }^{7}$.

6 Por. M. Adams-Tukiendorf, Jak efektywnie przygotować uczniów do pisania w języku obcym na egzaminie maturalnym, „Języki Obce w Szkole” 2006, nr 1, s. 50.

7 Por. A. Davies, H. G. Widdowson, Czytanie i pisanie, [w:] Kurs edynburski językoznawstwa stosowanego, J. P. B. Allen, S. Pit Corder (red.), t. 2, Warszawa 1983, s. 153-154. 
Istota pisania polega na wykonywaniu wielu operacji umysłowych jednocześnie. Dotyczą one decyzji na poziomie treści i formy, np. przełożenia myśli w formę językową, przywoływania wiedzy z zakresu tematu, planu wypowiedzi, konieczności selekcji informacji, planowania na poziomie pragmatycznym, przywoływania z pamięci odpowiednich elementów wypowiedzi, integrowania ich $z$ resztą tekstu. Dochodzą do tego poprawki edytorskie, ponowne czytanie, modyfikowanie w zależności od poziomu językowego piszącego. Piszący musi cały czas wykorzystywać informacje przechowywane w pamięci długotrwałej. Równocześnie musi mieć także w pamięci roboczej kontekst zdania i rosnący pod względem długości tekst ${ }^{8}$.

Aby nasze myśli nabrały postaci językowej, należy zastosować odpowiednie środki ${ }^{9}$. Musimy zauważyć, że środki wyrazu pisma nie wyczerpują się w literach alfabetu. Pismo operuje własnymi sposobami przekazywania informacji. Obok interpunkcji, która poza funkcją delimitacyjną oddaje określone różnice intonacyjne (zdania oznajmujące, pytające, rozkazujące), pismo wykorzystuje nieposiadające odpowiedników dźwiękowych środki graficzne, np.: różny krój czcionki (np. w komputerze Times New Roman, Arial, Courier, Century Gothic itd.), styl czcionki (normalny, pogrubiony, kursywa), rozmiar czcionki, podkreślenie (jedna linia ciągła, dwie linie ciągłe, linia przerywana) lub jego brak, kolor, odstępy, podział na akapity, zwrotki, numerowanie poszczególnych fragmentów tekstu czy stosowanie nagłówków ${ }^{10}$.

Ważną kwestią jest również fakt, iż w trakcie pisania mamy więcej czasu na przemyślenie naszych intencji, tematu, formy wypowiedzi niż podczas ustnej komunikacji, a w związku z tym także na dokładniejsze zastosowanie się do kryteriów jakości językowej, które są bardziej rygorystyczne w odniesieniu do pisania niż do mówienia. Tempo redagowania wypowiedzi pisemnej może być dowolnie regulowane przez piszącego. Piszący ma często dość czasu, aby przemyśleć i przeredagować tekst, a proces jego czytania może być wielokrotnie powtórzony. Korzystną okolicznością w trakcie pisania jest to, że uczący się nie jest skazany na ograniczenia własnej pamięci roboczej, więc może skorzystać z pamięci zewnętrznej, posiłkując się słownikami, leksykonami, może coś ponownie przepisać i zmodyfikować11.

8 Por. Th. C. Cooper, Schreiben als Prozess, oder „zurück zur Natur” in der Didaktik des Schreibens im DaF-Unterricht, [w:] Texte schreiben im Germanistik Studium, M. Lieber, J. Posset (red.), München 1988, s. 163-164; M. Dakowska, Psycholingwistyczne podstawy dydaktyki języków obcych, Warszawa 2001, s. 173.

9 Por. E. Łuczyński, J. Maćkiewicz, Językoznawstwo..., Gdańsk 2002, s. 59.

10 Por. H. Glück, Schreiben in der Fremdsprache..., s. 29; E. Awramiuk, Lingwistyczne podstawy..., s. 30 .

11 Por. W. Börner, Zum Erwerb von Textsortenkompetenz durch Schreiben, [w:] Praktische Handreichung für Fremdsprachenlehrer, U. H. Jung (red.), Frankfurt/Main 1992, s. 297; M. Dakowska, Psycholingwistyczne podstawy..., s. 168. 
Pisanie jest aktem dynamicznego komponowania, w trakcie którego jednocześnie odbywają się procesy planowania, przypominania, wnioskowania, budowania obrazu odbiorcy i testowania tego obrazu w świetle powstającego dyskursu. Piszący musi sprostać wielu wymaganiom odnośnie wiedzy językowej, pozajęzykowej, dyskursu pisemnego oraz problemu retoryki równocześnie. Musi on również dostosować środki językowe do lokalnych warunków, unikać powtórzeń i nieporadności stylistycznych. Każdy tekst w formie pisemnej wymaga zastosowania odpowiednich konstrukcji gramatycznych, odpowiedniego słownictwa, frazeologii, właściwej formy oraz właściwych konwencji stylistycznych ${ }^{12}$.

Proces pisania jest aktem twórczym, podczas którego powstaje pewien tekst, a piszący zachowuje się podobnie jak artysta malujący obraz. Malarz patrzy na swoje dzieło, oddala się, przybliża do sztalug, ocenia światło padające na płótno. Piszący szuka odpowiedzi na pytanie, co ma napisać w świetle kontekstu komunikacyjnego i swojej wiedzy o świecie, jaką formę temu nadać, planuje, dobiera właściwe środki językowe, łączy je i zapisuje. Pisząc tekst jednocześnie go czyta, dokonuje jego edycji i korekty oraz wykorzystuje informacje zwrotne (w warunkach szkolnych - od nauczyciela $)^{13}$.

\section{Pisanie w procesie nauki języka obcego}

Pisanie dla potrzeb dydaktyki obcojęzycznej możemy podzielić na ${ }^{14}$ :

a) pisanie kierowane:

- pisanie w funkcji wspierającej,

- pisanie w funkcji głównej,

b) pisanie wolne:

- pisanie zorientowane na problem,

- pisanie kreatywne.

Rola pisania kierowanego w funkcji wspierającej sprowadza się do pomocy w zapamiętywaniu nowego materiału językowego, np. w postaci notatek w zeszycie, pisemnych ćwiczeń wdrażających lub kontrolnych. Nie chodzi tu o rozwijanie sprawności samodzielnego pisania, a raczej o wykorzystywanie pisania jako środka

12 Por. M. Dakowska, Psycholingwistyczne podstawy..., s. 174.

13 Por. I. Mohr, Lernertexte untersuchen und überarbeiten: eine Übung aus dem DaF-Unterricht, [w:] Erfahrungen beim Schreiben in der Fremdsprache Deutsch, H. J. Krumm (red.), Insbruck-WienMünchen 2000, s. 112; A. Weirath, Der muttersprachliche und der fremdsprachliche Schreibprozess zwei Seiten einer Medaille?, [w:] Sprachlehrforschung im Wandel, B. Helbig, K. Kleppin, F. G. Königs (red.), Tübingen 2000, s. 405; B. Krischer, Schreiben - aber wie? Ein Planungsmodell, „Info DaF” 2002, nr 5, s. 389.

14 Por. R. Faistauer, Wir müssen zusammenschreiben! Kooperatives Schreiben im fremdsprachlichen Deutschunterricht, Innsbruck - Wien 1997, s. 67-68. 
pomagającego utrwalać nowy materiał leksykalny, gramatyczny lub przećwiczone wcześniej wypowiedzi ustne oraz jako środka, który pozwala sprawdzać, jaki zakres materiału został już opanowany. W takich przypadkach funkcja i wartość komunikacyjna sporządzanego tekstu stanowią czynnik uboczny, a sprawą ważniejszą jest funkcja dydaktyczna wykonywanej przez ucznia czynności ${ }^{15}$.

Pisanie kierowane w funkcji głównej nazywane jest także pisaniem komunikatywnym lub funkcjonalnym. Podczas takiego rodzaju pisania chodzi o imitowanie sytuacji komunikacyjnych dnia codziennego, z którymi można spotkać się w rzeczywistości, np.: pisząc list (prywatny, oficjalny), życiorys, ogłoszenie, odpowiedź na ogłoszenia, list motywacyjny. Mimo iż są to sytuacje fikcyjne, ukierunkowane są one na interakcję, czyli nie tylko wypowiedzenie własnych myśli, ale zrobienie tego w taki sposób, aby zostały właściwie zrozumiane i zinterpretowane, i aby został osiągnięty określony cel komunikacyjny, na przykład żeby kogoś o czymś poinformować lub komuś coś wyjaśnić. Piszący występując w roli nadawcy, formułuje komunikat, adresując go do jakiejś osoby - odbiorcy. Już zatem $\mathrm{w}$ trakcie formułowania przekazu musi wziąć pod uwagę pełnioną przez odbiorcę rolę społeczną, a podczas budowania wypowiedzi nadzorować i modyfikować jej planowanie, dokonywać selekcji przekazywanych informacji i kontrolować kształt wypowiedzi z uwagi na wybrane kryteria jakości ${ }^{16}$.

Obok pisania kierowanego mamy także pisanie wolne, które ma szeroką funkcję kształcącą. Podczas pisania wolnego uczący się może wyrażać swoje spostrzeżenia, uwagi, przemyślenia czy uczucia. Równocześnie uczy się on stosować odpowiednie struktury językowe, tj. konwencje retoryczne właściwe różnym rodzajom dyskursu, powtarza wcześniej poznane struktury i zestawy leksykalne oraz ćwiczy umiejętność komponowania tekstu. Pisanie wolne dzieli się na dwie podgrupy: pisanie zorientowane na problem i pisanie kreatywne. W tym miejscu należy podkreślić, iż kategoria pisania zorientowanego na problem odgrywa istotną rolę na zajęciach $\mathrm{z}$ języka obcego i jest chętnie stosowanym przez nauczycieli języków obcych środkiem dydaktycznym. Podczas takiego rodzaju tworzenia wypowiedzi pisemnych, na przykład w postaci rozprawek, uczący się musi w kompleksowej formie przekazać pewne informacje dotyczące jakiegoś zagadnienia i przedstawić swój punkt widzenia na dany temat (np.: „Schreiben Sie einen Aufsatz...", „Nehmen Sie Stellung“, „Begründen Sie“).

Pisanie $\mathrm{w}$ języku obcym można również rozpatrywać w aspekcie pisania kreatywnego nazywanego także pisaniem twórczym w postaci tzw. wypracowań

15 Por. także H. Komorowska, Metodyka nauczania języka obcego, Warszawa 1999, s. 203; A. Weirath, Der muttersprachliche..., s. 403; B. Krischer, Schreiben - aber wie..., s. 384.

16 Por. W. Börner, Zum Erwerb von Textsortenkompetenz..., s. 297; M. Dakowska, Psycholingwistyczne podstawy..., s. 170-171. 
wolnych. W dydaktyce pisanie kreatywne jest rozumiane jako twórczy proces, kształtujący u uczących się wyobraźnię, rozwijający różnego rodzaju myśli i poglądy na wybrany temat. Pisanie kreatywne jest zatem pewnym przelaniem na papier pomysłów i wyobraźni piszącego. Odwołuje się ono do czynników indywidualnych oraz emocjonalnych. Pisanie kreatywne polega na utworzeniu przez uczącego się określonego tekstu na podstawie gotowej lub własnej intencji komunikatywnej. Kreatywność wyrażana jest tutaj przez samodzielny wybór dowolnych jednostek leksykalnych, struktur gramatycznych, kolejność przekazywanych treści, samodzielną pracę ze słownikiem, samokontrolę i autokorektę. Podczas pisania kreatywnego osoba pisząca rozwija swoje zdolności asocjacyjne, organizacyjne i kompozycyjne w zakresie tworzenia tekstu pisanego o zróżnicowanej stylistyce, tak by przekazać różnorodne informacje w kompleksowej formie, zachowując poprawną strukturę języka i reguły wybranych rodzajów pisemnych wypowiedzi ${ }^{17}$.

\section{Wyniki badania - dane i ich analiza}

Punktem wyjścia niniejszego badania empirycznego była ankieta przeprowadzona w latach 2010-2013 wśród 109 studentów III roku lingwistyki stosowanej (specjalności: język niemiecki z językiem rosyjskim i język angielski z językiem niemieckim) studiów pierwszego stopnia Uniwersytetu Kazimierza Wielkiego w Bydgoszczy oraz jej analiza jakościowo-ilościowa.

Studenci czterech kolejnych roczników lingwistyki zostali poproszeni na pierwszych zajęciach z praktycznej nauki języka niemieckiego - pisanie z ortografią (2 godziny tygodniowo) o anonimowe wypełnienie ankiety. Wypełnienie kwestionariuszy było dobrowolne. Tylko jeden raz zdarzyło się, że jedna z badanych osób oddała pustą kartkę.

Ankieta zawierała 7 pytań o charakterze otwartym, dzięki czemu zebrano dużą ilość ciekawych informacji dotyczących sprawności pisania w języku niemieckim na poziomie zaawansowanym. W tym miejscu należy dodać, że otwarty charakter pytań często wyklucza analizę ilościową. Dlatego dokonano jakościowej interpretacji danych, a wyniki ankiety podano w formie opisowej.

W pierwszym pytaniu zapytano studentów „Co sprawia Pani/Panu trudność podczas pisania w języku obcym?”. Badani wymieniali najczęściej problemy z gramatyką (69 osób), ortografią (21 osób) oraz interpunkcją (18 osób). Pisali także: „Mam problem z kreatywnością, twórczym myśleniem i bogactwem językowym”,

17 Por. M. Laskowski, Pisanie kreatywne na poziomie szkoły średniej, „Lingwistyka Stosowana. Applied Linguistics. Angewandte Linguistik" 2010, nr 2, s. 133-134. 
„Trudność sprawia mi dobór odpowiedniego słownictwa i stylu”, „Największą trudność $\mathrm{w}$ pisaniu $\mathrm{w}$ języku obcym sprawia mi przekazanie myśli na papier. Myśląc w języku polskim trudno jest układać ładne, składne i sensowne zdania", „Trudność w odpowiednim oddaniu swoich myśli, by odbiorca zrozumiał, o czym myślałam”, "Często nie wiem, o czym mogłabym pisać". Jedna osoba napisała nawet: „Jak piszę w języku obcym to wszystko mi się razem miesza”.

Badani boją się możliwości popełnienia błędu. Uczucie trudności pogłębia świadomość badanych, że nie posiadają oni takich możliwości wypowiedzenia się w języku obcym jak w języku ojczystym.

W tym kontekście zapytano studentów: „Co sprawia Pani/Panu największą trudność podczas pisania w języku niemieckim?” (Pytanie 2). Studenci podawali, że problem sprawiają im ubogie słownictwo, dobór właściwych jednostek leksykalnych, interpunkcja, gramatyka, nowa pisownia niektórych wyrazów, logiczne uporządkowanie tworzonej wypowiedzi i pisanie pięknym stylem właściwym danemu rodzajowi tekstu. Oto przykładowe odpowiedzi badanych: „Często przekładam dosłownie z języka polskiego na niemiecki, kiedy brakuje mi słowa lub np. związku frazeologicznego”, „Największą trudnością podczas pisania w języku niemieckim okazuje się dla mnie za mały zasób słownictwa lub wyjątki w gramatyce”, „Często brakuje mi słów i nie wiem, jak coś wyrazić”, „Nie bardzo wiem, co mam pisać".

$\mathrm{Z}$ analizy odpowiedzi na dwa pierwsze pytania wynika, iż zasadniczą przyczyną kłopotów podczas pisania w języku obcym, np. w języku niemieckim, są przeszkody wynikające ze względów czysto językowych, czyli nieznajomości lub braków w zakresie form gramatycznych, ortografii czy niewystarczającej znajomości leksyki. Towarzyszy im odczucie trudności na poziomie pojęciowym, które powoduje u badanych trudności z określeniem intencji komunikacyjnych, czyli problem wynikający z tego, że student nie wie, co ma napisać. Ankietowani zdają sobie sprawę, iż podczas pisania istotne są nie tylko poprawność językowa i stosowanie właściwych konstrukcji leksykalno-gramatycznych, lecz także zachowanie odpowiedniej formy oraz umiejętność zwięzłego przekazu informacji i umiejętności kompozycyjno-stylistyczne. Dakowska ${ }^{18}$ słusznie podkreśla, że istotnym elementem konstruowania dyskursu jest ustalenie treści na poziomie pojęć i sądów. Niepewność odnośnie tego, co badany chce powiedzieć lub niejasny charakter powstających dopiero myśli, które chce przekazać, może być dla autora źródłem odczuwalnego napięcia. Problem, co napisać, jest tak samo skomplikowany jak dobór formy, słownictwa, zwrotów, których może brakować do wyrażenia znaczeń.

18 Por. M. Dakowska, Psycholingwistyczne podstawy..., s. 174. 
W tym miejscu warto dodać, iż tworzone przez uczących się teksty powinny być przeczytane lub wysłuchane, poprawione i skomentowane przez nauczyciela. Bardzo często bowiem, nawet u zaawansowanych, tworzenie tekstu w języku obcym nie przebiega na gruncie nabywanego języka, lecz na gruncie języka ojczystego. Piszący tworzy w języku ojczystym zarys tego, co chciałby napisać. Do tego zarysu dobiera zakodowane w pamięci obcojęzyczne elementy znakowe (wyrazy, połączenia wyrazowe, zdania) i strukturalne. W procesie tworzenia tekstu w języku obcym mamy więc często do czynienia z tłumaczeniem polskich treści na język obcy, a nie z tworzeniem tekstu obcojęzycznego bezpośrednio w języku obcym. W konsekwencji podczas pisania przez polskiego ucznia, tu w języku niemieckim, działa interferencja językowa, np. w podsystemie gramatycznym czy leksykalnym.

Jak wiadomo, stan idealnego opanowania języka nie istnieje i na każdym etapie zachodzi prawdopodobieństwo popełnienia błędu językowego, co częściowo potwierdziły już odpowiedzi na poprzednie pytania. W pytaniu 3 poproszono więc studentów, aby podali, jakie problemy gramatyczne są przyczyną błędów w ich pracach pisanych po niemiecku. Studenci odpowiadali, że trudności sprawiają im: szyk wyrazów w zdaniu (75 osób), rodzajniki (59 osób), rekcja czasownika i przymiotnika (54 osoby), końcówki przymiotnika (37 osób), czasowniki rozdzielnie złożone (25 osób) oraz formy nieregularne czasownika (30 osób).

Kolejnym problemem jest nieznajomość elementów leksykalnych, służących do wyrażenia intencji komunikacyjnej we właściwej formie. Dlatego w następnym pytaniu zapytano badanych (Pytanie 4): „Czy niemieckie słownictwo sprawia Pani/Panu trudność podczas pisania dłuższych wypowiedzi?”. Dziewiętnaście osób odpowiedziało „Nie”. Pozostali respondenci podawali, iż mają problemy ze słówkami, np.: „Czasem tworzę słówka, których nie ma”, „Niekiedy brakuje mi słówka”, „Nie mam opanowanego wystarczająco słownictwa na każdy temat”, „Trudnością jest zbyt mały zasób słownictwa, a w każdym wypracowaniu mam obawy użyć nowo poznane słówka, żeby nie zrobić błędu”.

Aby dobrze pisać w języku obcym, należy doskonalić swoją wiedzę w określonym zakresie, by posiadać w swojej pamięci dużą ilość pojęć i sądów na dany temat. Pomocne jest także posiłkowanie się różnego rodzaju źródłami informacji, np.: słownikami, leksykonami czy artykułami z czasopism. Duża ilość myśli, tj. rozbudowany system wiedzy na określony temat pozwala dokonywać wyboru informacji i ich łączenia, ułatwia szybsze, sprawniejsze pisanie i przedstawienie tekstu w sposób zrozumiały z perspektywy czytającego, umożliwia wychwycenie własnych niedoskonałości i poprawienie ewentualnych błędów w tekście.

Dzięki ankiecie można było się także dowiedzieć, czy studenci lubią pisać dłuższe wypowiedzi w języku niemieckim (Pytanie 5). Tylko 10 osób odpowiedziało, że nie, a uzasadniły to w ten sposób: „Nie ponieważ zajęcia są zbyt 
krótkie, by dokładnie przemyśleć pracę”, „Nie z obawy przed dużą ilością błędów, brakuje mi inwencji”, „Nie bo zajęcia i egzaminy są za krótkie i nie mam czasu dokładnie przemyśleć pracy, pojawiają się błędy z pośpiechu”, „Nie lubię, ponieważ zamiast na treści muszę się skupić bardziej na gramatyce, muszę zrezygnować z tego, co chcę przekazać, aby nie popełnić błędu”, „Nie bo wciąż myślę o błędach i nie mam czasu na treść". Pisanie wiąże się z koniecznością przemyślenia tematu, a to zabiera niektórym osobom często więcej czasu niż samo zapisanie myśli na kartce papieru. Czasu wymaga też analiza tekstu, np.: uzupełnianie, wykreślanie, poprawianie błędów itd. Uczący się nie lubią pisać podczas zajęć lub egzaminów, bo wiąże się to z limitem czasu. Demotywujące są także błędy - piszący ma przed sobą dowód na to, jakie posiada umiejętności językowe ${ }^{19}$.

Reszta ankietowanych udzieliła pozytywnej odpowiedzi. Badani pisali: „Tak mimo obawy o błędy, dzięki temu mogę wyrazić swoje myśli oraz poszerzyć zdolności językowe”, „Lubię pisać rozprawki, opowiadania, bo lubię przelewać swoje myśli na papier”, „Lubię pisać, ponieważ jestem humanistką, uwielbiam uzewnętrzniać swoje myśli i emocje na papierze, przychodzi mi to łatwo, nie mam problemów z szukaniem argumentów”, "Tak zwłaszcza jak mi podpasuje temat”, „Lubię pisać, bo łatwiej mi pisać niż mówić. Poza tym można wtedy widzieć swoje błędy, uczyć się na nich. Pisząc poprawiamy także zasób słownictwa i swoje wiadomości”, „Bardzo lubię pisać dłuższe wypowiedzi w języku niemieckim. Pisać można na spokojnie, wszystko można sprawdzić. Uważam, że pisanie to łatwiejsza forma komunikacji niż mówienie. Niekiedy przy mówieniu można się zdenerwować, przy pisaniu tak nie jest”, „Tak bo się uczę. Poza tym gdy praca jest sprawdzana przez wykładowcę, wiem jakie robię błędy i staram się ich unikać podczas pisania kolejnych prac". Z pozytywnych odpowiedzi studentów wynika, iż cechuje ich dojrzałość poglądów, ponieważ są świadomi tego, że mogą popełnić błąd, ale wiedzą, że na błędach można się uczyć. Badanym sprawia przyjemność pisanie wypracowań wolnych. Studenci lubią pisać po niemiecku o swoich osobistych przeżyciach i doświadczeniach, przy czym ważnymi argumentami, które tu wymieniają, są ich zainteresowania oraz ćwiczenie i poprawa własnej znajomości języka niemieckiego. Studenci lubią pisać w języku niemieckim, ponieważ forma pisemna pozwala im na dłuższe zastanowienie się niż wypowiedź ustna.

W tym kontekście zapytano studentów: „Czy opanowanie sprawności pisania w języku niemieckim ma sens?” (Pytanie 6), na co wszyscy badani zgodnie odpowiedzieli „tak". Uzasadniali to faktem, że ta sprawność może się im przydać w przyszłości, np.: w pracy zawodowej, w bezpośrednich kontaktach z Niemcami czy innymi cudzoziemcami, podczas korespondencji e-mailowej czy w dalszych

19 Por. M. Adams-Tukiendorf, Jak efektywnie przygotować..., s. 51. 
studiach, np.: „Daje mi szansę na bycie profesjonalnym w przyszłej pracy, taka umiejętność zawsze się przydaje”, „Oczywiście że tak, aby dobrze opanować język trzeba sobie dobrze radzić we wszystkich sprawnościach”, „Tak, bo wiele spraw można nadal załatwić tylko drogą pisemną”, „Tak ponieważ można nauczyć się różnych konstrukcji, które można wykorzystać w życiu codziennym, np. w korespondencji internetowej ze znajomymi Niemcami. Przy pisaniu poszerza się słownictwo".

Na koniec poproszono studentów, aby każdy napisał, co chciałby poprawić w swojej sprawności pisania w języku niemieckim (Pytanie 7). Studenci przede wszystkim chcieliby lepiej pisać pod względem interpunkcji, ortografii i gramatyki. Badani chcieliby także wzbogacać znajomość niemieckiego słownictwa i umieć dostosować słownictwo do stylu wypowiedzi, aby pisać dojrzałe i ciekawe pod względem treści prace. Studenci chcą umieć pisać w sposób swobodny i zwięzły, wykorzystując własne doświadczenia życiowe. Chcą być twórczy i samodzielni, chcą koncentrować się na treści, a nie tylko na poprawności językowej tworzonego tekstu. Oto przykładowe odpowiedzi ankietowanych: „Chciałabym umieć pisać nie tylko rozprawki i opowiadania, ale także listy, ogłoszenia, oferty, reklamacje, umowy, listy motywacyjne”, „Chciałabym umieć pisać zwięźle i zrozumiale”, „Chciałbym umieć swobodnie pisać na każdy temat, abym mógł wyrazić swoje zdanie, a nie tylko myśleć o tym, żeby nie zrobić błędu”, „Chciałabym umieć pisać obszerniejsze, bardziej złożone teksty w różnych czasach i formach”, „Chciałabym popełniać mniej błędów stylistycznych, używać różnych konstrukcji, wyrażeń językowych, które wzbogaciłyby moją pracę i dzięki którym byłaby ona ciekawsza”, „Chciałbym mieć lepsze pióro, bo czasami ciężko zebrać mi myśli i wymyślać argumenty”, „Chciałabym umieć pisać po niemiecku o wszystkich sprawach”.

\section{Podsumowanie}

Pisanie daje możliwość systematyzacji utrwalanego materiału językowego, kształtowania i wykorzystania pamięci piszącego oraz wiedzy językowej w procesie nauki języka obcego. Dzięki pisaniu uczący się poszerza swój repertuar słów, może snuć refleksje o języku, może nie tylko sam tworzyć teksty, ale także oceniać i wyrażać w nich własną opinię.

Tworząc teksty w formie pisemnej, student lepiej poznaje język, uczy się odwzorowywania rzeczywistości (np. jej wycinków wskazanych w temacie), kształci postrzeganie, obserwację, umiejętność analizy i werbalizacji własnych doświadczeń oraz korzystania z różnych źródeł informacji. Uczy się precyzyjnego myślenia, wrażliwości i koncentracji uwagi. Rozwija także postawy twórcze, aby pisać interesująco, z zaangażowaniem, pokonując trudności językowe i opór 
w przypadku tematu, który mu nie odpowiada. Dzięki pisaniu student usprawnia operacje zdaniotwórcze, umiejętność doboru właściwych środków i struktur językowych do tematu, formy, adresata i funkcji. Dodajmy, że dzięki pisaniu w języku obcym zostają rozwinięte i wzmocnione umiejętności kompozycyjno-stylistyczne piszącego także w zakresie języka ojczystego.

Na koniec chciałabym zacytować jednego z moich studentów: „Warto pisać po niemiecku, tak samo jak warto mówić, aby język ten stał się narzędziem, którym posługiwanie się jest dla nas przyjemnością".

\section{Bibliografia}

Adams-Tukiendorf M., Jak efektywnie przygotować uczniów do pisania w języku obcym na egzaminie maturalnym, „Języki Obce w Szkole” 2006, nr 1, s. 50-60.

Awramiuk E., Lingwistyczne podstawy początkowej nauki czytania i pisania po polsku, Białystok 2006.

Bawej I., Pisemna forma komunikacji językowej w procesie nauki języka obcego, „Linguistica Bidgostiana" 2008, t. 5, s. 22-36.

Börner W., Zum Erwerb von Textsortenkompetenz durch Schreiben, [w:] Praktische Handreichung für Fremdsprachenlehrer, U. H. Jung (red.), Frankfurt/Main 1992, s. 297- 309.

Cooper Th. C., Schreiben als Prozess, oder "zurück zur Natur" in der Didaktik des Schreibens im DaF-Unterricht, [w:] Texte schreiben im Germanistik Studium, M. Lieber, J. Posset (red.), München 1988, s. 163-175.

Dakowska M., Psycholingwistyczne podstawy dydaktyki języków obcych, Warszawa 2001.

Davies A., Widdowson H. G., Czytanie i pisanie, [w:] Kurs edynburski językoznawstwa stosowanego, J. P. B. Allen, S. Pit Corder (red.), t. 2, Warszawa 1983, s. 132-157.

Faistauer R., Wir müssen zusammenschreiben! Kooperatives Schreiben im fremdsprachlichen Deutschunterricht, Innsbruck - Wien 1997.

Glück H., Schreiben in der Fremdsprache Deutsch. Eine Einführung, [w:] Texte schreiben im Germanistik Studium, M. Lieber, J. Posset (red.), München 1988, s. 25-38.

Komorowska H., Metodyka nauczania języka obcego, Warszawa 1999.

Krischer B., Schreiben - aber wie? Ein Planungsmodell, „Info DaF” 2002, nr 5, s. 383-408.

Laskowski M., Pisanie kreatywne na poziomie szkoły średniej, „Lingwistyka Stosowana. Applied Linguistics. Angewandte Linguistik" 2010, nr 2, 133-143.

Łuczyński E., Maćkiewicz J., Językoznawstwo ogólne. Wybrane zagadnienia, Gdańsk 2002.

Mohr I., Lernertexte untersuchen und überarbeiten: eine Übung aus dem DaF-Unterricht, [w:] Erfahrungen beim Schreiben in der Fremdsprache Deutsch, H. J. Krumm (red.), Insbruck - Wien - München 2000, s. 109-155.

Weirath A., Der muttersprachliche und der fremdsprachliche Schreibprozess - zwei Seiten einer Medaille?, [w:] Sprachlehrforschung im Wandel, B. Helbig, K. Kleppin, F. G. Königs (red.), Tübingen 2000, s. 403-413. 